\title{
SENYVO AMŽIAUS CUKRINIU DIABETU SERGANČIŲJŲ GYVENIMO KOKYBĖS, MOKYMOSI MOTYVACIJOS IR SLAUGYTOJO DIABETOLOGO VAIDMENS SĄSAJOS
}

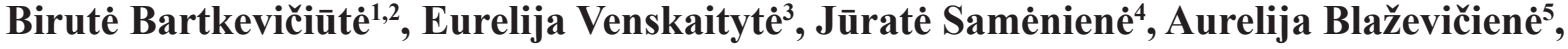 \\ Virginija Bulikaite் ${ }^{6}$ \\ ${ }^{1}$ AB Birštono sanatorija ,Versmé“, ${ }^{2}$ Alytaus kolegija, ${ }^{3}$ Lietuvos sporto universitetas, \\ Sporto mokslo ir inovaciju institutas, ${ }^{4}$ Lietuvos sveikatos moksly universiteto \\ Medicinos akademijos Slaugos fakultetas, Reabilitacijos klinika, \\ ${ }^{5,6}$ Lietuvos sveikatos moksly universiteto Medicinos akademijos Slaugos ir rūpybos katedra
}

Raktažodžiai: slaugytojas diabetologas, sergančiųjų cukriniu diabetu gyvenimo kokybè, cukrinis diabetas, senyvo amžiaus pacientas.

\section{Santrauka}

Lietuvos, kaip ir kitų Europos valstybių, visuomenè sparčiai sensta. Kintančios demografinès tendencijos: gyventojų senejjimas, gyvenimo trukmès ilgèjimas, asmenų, sergančių lètinèmis ligomis (pvz., cukriniu diabetu (CD), osteoartroze), gausèjimas daro poveiki asmens fizinei psichologinei ir socialinei gerovei. Dèl to daugeliui senų žmonių reikia ivairių paslaugų. Lietuvos sveikatos statistikos duomenimis, Lietuvoje nuolat didejja sergančiųu CD skaičius. Ši lètinè liga lemia reikšmingą sergamumą ir mirtingumą. Didelis visuomenès sveikatos iššūkis yra CD tarp vyresnio amžiaus pagyvenusių žmonių. Vyresnio amžiaus ligoniai, sergantys CD ir dažnai kenčiantys nuo hipoglikemijos epizodų, kur kas labiau rizikuoja susirgti demencija.

Tikslas - nustatyti senyvo amžiaus cukriniu diabetu sergančiujų gyvenimo kokybès, mokymosi motyvacijos ir slaugytojo vaidmens sąsajas.

Tyrimo metodika ir metodai. Tyrimas atliktas Lietuvos diabeto asociacijoje (LDA). Pasirinktas anoniminès anketinès apklausos metodas. Tyrime, atliktame 2013 m. kovo-gruodžio mèn., dalyvavo 122 LDA nariai: 60 metu ir vyresni, sergantys 1 tipo ir 2 tipo CD. Duomenu analize buvo atlikta su SPSS (angl. Statistical Package for the Social Sciences) programiniu paketu, 19,0 versija.

Rezultatai. Beveik pusè respondentų nurode, kad jų dabartinè gyvenimo kokybè yra vidutiniška $-\mathrm{n}=55$
$(45,1 \%)$ 0,39 $(0,770)$ balo. Atsakymai apie numanomą jų gyvenimo kokybę rodo - jei jie nesirgtų $\mathrm{CD}$, jų gyvenimo kokybė būtų daug geresnè $\mathrm{n}=$ 46 (37,8 proc.) - 2,41 (0,092) balo. Reikšminga atvirkštinè koreliacija buvo gauta tarp pacientų žinių apie CD ir pacientų žinių apie slaugytojo diabetologo teikiamas specializuotas slaugos paslaugas $(r=-$ $0,146, \mathrm{p}=0,020$ ).

Išvados. Slaugytojas diabetologas siekia padèti sergantiems CD laikytis gydymo ir slaugos rekomendacijų, skatina elgsenos pokyčius ir jų išlaikymą, aiškinasi ir sprendžia kylančius neaiškumus. Sergantieji CD tikisi tikslios, suprantamos informacijos apie savo ligą, jos baigti. Mokymas yra vienas iš veiksnių, darančių teigiamą ịtaką sergančiųjų CD gyvenimo kokybei.

\section{Ivadas}

Lietuvos, kaip ir kitų Europos valstybių, visuomenė sparčiai sensta. Mūsų šalyje per pastaruosius 60 metų sparčiai padaugèjo vyresnių nei 60 metų amžiaus žmonių skaičius bei daugiau nei pusantro karto sumažejo vaikų iki 15 metų amžiaus dalis. Gimstamumo, mirtingumo ir migracijos dinamika daro ịtaką gyventojų skaičiaus mažejimui. Natūrali kaita, gimstamumo ir mirtingumo santykis, intensyvi emigracija, kurios didžiają dali sudaro 20-29 metų amžiaus žmonès - šie esami gyventojų amžiaus struktūros charakteristikos pokyčiai nuo XX a. dešimtojo dešimtmečio paspartino senejjimo tempus. Prognozuojama, kad 2030 m. pradžioje beveik trečdali ( 28,9 proc.) Lietuvos gyventojų sudarys 60 metų ir vyresnio amžiaus asmenys (Europos Sajungos (toliau - ES) 27 šalių vidurkis - 30,4 proc.). Siekiant duomenų palyginimo, Pasaulio senejjimo asamblèja 
demografiniu senumo kriterijumi pasiūlè laikyti 60 metų ribą (iki $60 \mathrm{~m}$. - vidutinis amžius, nuo $60 \mathrm{~m}$. - vyresnis), „Sveiko senéjimo užtikrinimo Lietuvoje 2014-2023 m. veiksmų plane" nurodoma, kad geriatrinès sveikatos priežiūros paslaugos yra skirtos 60 metų ir vyresniems senyvo amžiaus žmonèms [1, 2, 21, 24-25].

Patvirtinus Pasaulio sveikatos organizacijos (PSO) visuomenès sveikatos priežiūros strateginio dokumento „Sveikata visiems XXI amžiuje“ principus, Europos šalys ịsipareigojo rūpintis žmonių sveikata, gerove ir patvirtino, kad siekis kuo geresnès sveikatos - viena pagrindiniu kiekvieno žmogaus teisių. Teigiama, kad didelis demesys skiriamas visuomenès sveikatos ugdymui ir lėtinių ligų (pvz.: $\mathrm{CD}$, širdies ir kraujagyslių ligų) rizikos veiksnių kontrolei, nes žinios apie sveikatą yra naudingos tiek neturintiems, tiek turintiems sveikatos problemų ar sergantiesiems lètinèmis ligomis bei sergančiųjų artimiesiems [22].

Kintančios demografinès tendencijos: gyventojų senejjimas, gyvenimo trukmès ilgèjimas, asmenų, sergančiu lètinèmis ligomis (pavyzdžiui, cukriniu diabetu (CD), širdies ir kraujagyslių ligomis, osteoartroze) daugèjimas daro poveiki asmens fizinei psichologinei ir socialinei gerovei bei kuria radikaliai naują ekonominį ir socialinị kontekstą, didina socialinès, sveikatos apsaugos sąnaudas. Daugeliui senų žmonių atsiranda ịvairių paslaugų poreikis $[3,24]$.

Mokslinėje literatūroje senèjimo procesas apibrèžiamas kaip dèsningas biologinis procesas, kuris neišvengiamai atsiranda su amžiumi, pasireiškia laipsnišku organizmo prisitaikymo galimybių mažejimu, pagrindinių kūno ir psichikos funkcijų silpnejjimu, tiesiogiai priklauso nuo aplinkos, mitybos bei gyvenimo būdo ir požiūrio ị gyvenimą. Vyresnio amžiaus žmonès yra mažiau atsparūs ligoms. Apie 80 proc. vyresnių kaip 65 metų gyventojų serga viena iš šių lètinių ligų: 2 tipo $C D$, nutukimu, Alzheimerio liga, širdies ir smegenų kraujagyslių ligomis, navikais. Apie 50 proc. vyresnių kaip 65 metų gyventojų serga mažiausiai dviem lètinemis ligomis, jiems būdinga polipatologija (keletas lètinių ir ūmių ligų) ir polipragmazija (vartoja penkis-dešimt ir daugiau vaistų). Žmogui senstant, vyksta biologiniai pakitimai - endokrininès sistemos pokyčiai (pvz., CD), kvėpavimo organų (sumažèja gyvybinè ir bendra plaučiu talpa), plonėja širdies raumuo, vyksta pokyčiai virškinimo ir šalinimo sistemoje, mažeja inkstų pajègumas, atrofuojasi skeleto raumenys (raumenų maksimali jèga po 50 metu kasmet sumažejja po 1-3 proc.), jutimo organų pokyčiai. Vyksta motorinès, pusiausvyros, sensorinès sistemos pokyčiai, senka fizinès jègos. Osteoartritas - dažniausia pagyvenusių žmonių skeleto raumenų nusilpimo priežastis.

Amžius yra vienas iš kintamujų, turinčių įtakos CD paplisti. Atsparumas insulinui ir gliukozès tolerancijos sutrikimas (GTS) yra labiau paplitęs tarp vyresnio amžiaus žmonių nei jaunesnių, dėl to pastarieji yra labiau linkę sirgti 2 tipo CD. Priežastys, sąlygojančios pagyvenusių žmonių atsparumą insulinui: nutukimas, pakitęs riebalų pasiskirstymas (nyksta poodiniame sluoksnyje ir gausiai kaupiasi moterims ant liemens bei šlaunų, vyrams - pilvo srityje), létinis stresas, hormoniniai sutrikimai, netinkami mitybos įpročiai, mažèjantis fizinis aktyvumas, pajëgumas [23-24, 26, 27].

Lietuvos sveikatos statistikos duomenimis, Lietuvoje nuolat daugèja sergančiųjų CD skaičius [5]. CD yra sudètinga sveikatos problema, kuri lemia reikšmingą sergamumą ir mirtingumą $[6,7]$. Remiantis Tarptautinès diabeto federacijos duomenimis (TDF), $2015 \mathrm{~m}$. pasaulyje CD sirgo apie $415 \mathrm{mln}$. pasaulio 20-79 m. amžiaus gyventojų, Europoje - 59,8 mln. gyventojų, Lietuvoje - 116,9 tūkstančių žmonių. Liga nediagnozuota 44,1 tūkstančio 20-79 m. amžiaus Lietuvos gyventojų [4].

Sergantieji CD jaučia neigiamą ligos ịtaką visiems gyvenimo kokybès aspektams: psichinei, fizinei ir socialinei gerovei [8-10].

Su sveikata susijusios gyvenimo kokybės (SSSGK) išmatavimas yra svarbus, kalbant apie ligas, tokias kaip CD, ypač dèl to, kad ši liga reikalauja intensyviai rūpintis savo sveikata visą gyvenimą, gydymas yra brangus ir sudètingas, reikalauja nuolatinio švietimo, siekiant išvengti komplikacijų $[11,9,12]$.

PSO teigimu, slaugytojai yra sveikatos sistemų pagrindas visame pasaulyje. Jie turi gebėti valdyti platų multidisciplininių kompetencijų rinkinị, gebėti dirbti savarankiškai, bendradarbiauti su kitais komandos nariais, būti atsakingi už asmens sveikatos stiprinimą, ligų ir neigalumo prevenciją $[8,11,13]$.

Irane atliktame tyrime nustatyta, kad slaugytojai, teikdami sergantiems CD ir jų šeimoms reikalingą informaciją ir konsultacijas, per savirūpa igalina pacientus geriau valdyti CD. Mokymas yra visą gyvenimą trunkantis procesas, leidžiantis sergančiajam CD pasiekti aukščiausią ịmanomą lygi savarankiškai ir veiksmingai valdyti savo ligą $[14,8]$.

Slauga, orientuota ị visą šeimą, sudaro sąlygas numatyti galimybes keistis informacija apie pagrindinius slaugos komponentus, rūpintis šeimomis, ugdant pagarbą, bendradarbiavimą, paramą ir pasitikejjimą $[15,16]$.

Tyrimo tikslas - nustatyti senyvo amžiaus cukriniu diabetu sergančiujų gyvenimo kokybès, mokymosi motyvacijos ir slaugytojo vaidmens sąsajas.

\section{Tyrimo metodas ir medžiaga}

Tyrimas atliktas Lietuvos diabeto asociacijoje (LDA) 2013 m. kovo-gruodžio mèn. Atlikta anoniminè anketinè apklausa. Tyrime dalyvavo 122 LDA nariai: 60 metų ir vyresni, sergantys 1 tipo ir 2 tipo CD. Siekiant užtikrinti tyrimo reprezentatyvumą, imties dydžiui užtikrinti naudo- 
ta formulè: imties dydis $\mathrm{n}=[\mathrm{DEFF} * \mathrm{~Np}(1-\mathrm{p})] /[(\mathrm{d} 2 / \mathrm{Z} 21-$ $\alpha / 2 *(\mathrm{~N}-1)+\mathrm{p} *(1-\mathrm{p})][31]$.

Tyrimui atlikti buvo gautas Lietuvos sveikatos mokslu universiteto Medicinos akademijos (LSMU MA) Bioetikos centro leidimas 2013-01-09 Nr. BEC-KS(M)-179.

Tyrimui naudotas klausimynas susideda iš trijų dalių: pirma dalis - anketa apie CD sergančių pacientų gyvenimo kokybę ADDQoL (Audit of Diabetes - Dependent Quality of Life) [8]. Anketa susideda iš dviejų apžvalgos elementų: bendroji dalis ir 19 klausimų klausimynas. Tai: 1 kl. laisvalaikis, $2 \mathrm{kl}$. darbinès veiklos, 3-4 kl. sėslumas ar tolimos kelionès, šventès, $5 \mathrm{kl}$. fizinè sveikata, $6 \mathrm{kl}$. šeimos gyvenimas, $7 \mathrm{kl}$. draugyste ir socialinis gyvenimas, $8 \mathrm{kl}$. artimi asmeniniai santykiai, $9 \mathrm{kl}$. lytinis gyvenimas, $10 \mathrm{kl}$. išvaizda, $11 \mathrm{kl}$. pasitikèjimas savimi, $12 \mathrm{kl}$. motyvacija igyvendinti siekius, $13 \mathrm{kl}$. aplinkiniu reakcijos, $14 \mathrm{kl}$. nuojautos dèl ateities, $15 \mathrm{kl}$. finansinè padètis, $16 \mathrm{kl}$. buities sąlygos, $17 \mathrm{kl}$. priklausomybė nuo kitų, $18 \mathrm{kl}$. laisvès valgyti ir 19 kl. laisvès gerti. Šie 19 sričių klausimai prašo respondentų ịvertinti, koks būtu jų gyvenimas, jei jie nesirgtų diabetu. Anketos analizė vyksta pagal autorių pateiktą algoritmą, ivertinamas kiekvienas gyvenimo aspektas atskirai balais nuo -9 iki + 9 (labai blogai - labai gerai).

Antra dalis - tyrimo autoriu parengta anketa apie pacientu mokymosi motyvaciją, trečia dalis - tyrimo autorių parengta anketa apie slaugytojo diabetologo vaidmeni valdant ligą. Anketos analizè vyksta pagal autorių pateiktą algoritmą, i̇vertinant kiekvieną gyvenimo aspektą atskirais balais nuo - 9 iki 9 (kai -9 - labai blogai, o +9 - labai gerai).

Pasverto itakos koeficiento

vidurkis $=\frac{\text { itakos vertinimas } * \text { svarbos vertinimas }}{\mathrm{N}}$

Koeficiento vertinimas:

1. -9 - maksimali neigiama CD ịtaka

2. +9 - maksimali teigiama CD įtaka [32].

Itakos koeficiento vidurkis $=$ itakos vertinimas * svarbos vertinimas. Tyrimo autorių parengta anketa apie pacientų mokymosi motyvaciją (Kronbach'o alfa: $\alpha=0,82$ ).

Tyrimo autorių parengta anketa apie slaugytojo diabetologo vaidmenį valdant ligą (Kronbach'o alfa: $\alpha=0,74$ ). Demografiniai kintamieji - amžius, lytis, išsilavinimas, gyvenamoji vieta, užsièmimas - buvo ịvertinti pačių sukurtu klausimynu.

Tyrimo autorių parengtų klausimynų tinkamumui įvertinti, prieš pradedant tyrimą buvo atliktas žvalgomasis tyrimas, kurio tikslas buvo išsiaiškinti anketų pritaikomumą ir galimus trūkumus.

Duomenų analizė buvo atlikta su SPSS (angl. Statistical Package for the Social Sciences) programiniu paketu, 19,0 versija. Vertinant duomenis buvo skaičiuojami: aritmetinis vidurkis, standartinis nuokrypis, aritmetinio vidurkio paklaida, Spearmeno'o koreliacijos koeficientas (r) ir statisti- nis patikimumas (p). Duomenų, kurie netenkino normaliojo pasiskirstymo sąlygų, analizei buvo naudojami MannWhitney (tarp dviejų grupių) ir Kruskal-Wallis (daugiau nei dvi grupès) testai. Pasirinktas statistinio reikšmingumo lygmuo $\mathrm{p}<0,05$.

Tyrime dalyvavo $\mathrm{n}=12260-83 \mathrm{~m}$. (amžiaus vidurkis $68 \mathrm{~m}$.) sergantieji $\mathrm{CD}, \mathrm{n}=79$ (64,7 proc.) moterys ir $\mathrm{n}=43$ (35,3 proc.) vyrai. Pagal išsilavinimą trečdalis respondentų $\mathrm{n}=35$ (28,5 proc.) turejo aukštajị universitetinị išsilavinimą, $\mathrm{n}=17$ (13,9 proc.) - aukštesnijji, daugiausiai $\mathrm{n}=70$ (57,6 proc.) - vidurinị ar žemesni išsilavinimą. Miesto gyventojai sudare didesnę dali $\mathrm{n}=85$ (69,7 proc.), kaimo $\mathrm{n}=$ 37 (30,3 proc.) respondentų. Miesto gyventojai dažniausiai neigiamai vertina CD įtaką jų gyvenimo kokybei (vidurkis lygus $2,76 \pm 0,222)$.

\section{Tyrimo rezultatai}

Siekiant išsiaiškinti, kaip gyvenimo kokybè veikiama CD, šiame darbe apklausų metu buvo naudojama LTADDQoL anketa. Anketinés apklausos rezultatai parodè, kad bendras respondentų gyvenimo kokybès ịvertinimo vidurkis $0,39 \pm 0,077$ balo, o respondentų vertinimu, $C D$

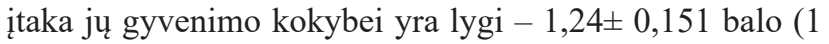
pav.). Bendras pasvertojo gyvenimo kokybès itakos koeficientas 1,09 .

Pateikti pagrindinių gyvenimo kokybès veiksnių pasverto ịtakos koeficiento vidurkiai atsižvelgiant ị individualius CD įtakos vertinimus. Kuo arčiau neigiamos 9 reikšmès yra šio vidurkio rezultatas, tuo didesnè neigiama CD itaka individo gyvenimo kokybei ir atvirkščiai. Labiausiai, respondentų nuomone, dèl CD nukenčia jų laisvalaikio veikla $(-1,17 \pm 0,25)$. Daugiau nei trečdalis apklaustujų galvoja $\mathrm{n}=33$ (27 proc.), kad laisvalaikio veikla jiems yra svarbi, daugiausia $n=45$ (36,9 proc.) respondentų atsakè, jog iš dalies svarbi. Truputị daugiau mėgautųsi laisvalaikiu, jeigu nesirgtų CD $n=45$ (36,9 proc.) apklaustujų (2 pav.)

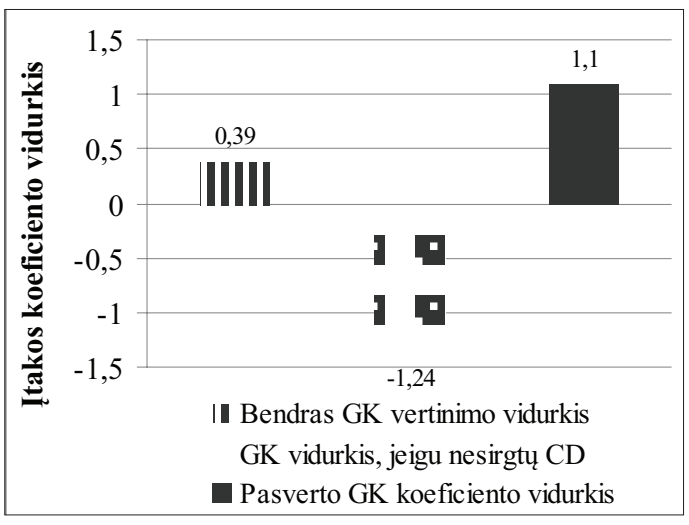

1 pav. Bendras gyvenimo kokybès įvertinimas 
Beveik pusė respondentų nurodé, kad jų dabartinė gyvenimo kokybė yra vidutinė $\mathrm{N}=55$ ( 45,1 proc.) ( 3 pav.).

Respondentų pasiskirstymas pagal lytị, vertinant esamą gyvenimo kokybę, pasiskirste panašiai. Tiek vyrai $\mathrm{n}=20$ (46,5 proc.) vidurkis $0,26 \pm 0,26(0,120)$, tiek moterys $n=$ 35 (44,3 proc.) vidurkis $0,47(0,098)$, nurodè, kad jų gyvenimo kokybė yra vidutinè. Puikiai savo gyvenimo kokybę vertino tik moterys $n=3$ (3,7 proc.) (4 pav.).

Pacientų atsakymai apie numanomą jų gyvenimo kokybę reiškia, kad, jei jie nesirgtų CD, jų gyvenimo kokybė būtų geresnè. Respondentų suvokimu, liga nulemia jų gyvenimo kokybę. $\mathrm{n}=46$ (37,8 proc.) apklaustujų nurodè, kad jų gyvenimo kokybė būtų daug geresnè, o n $=55(57,4$

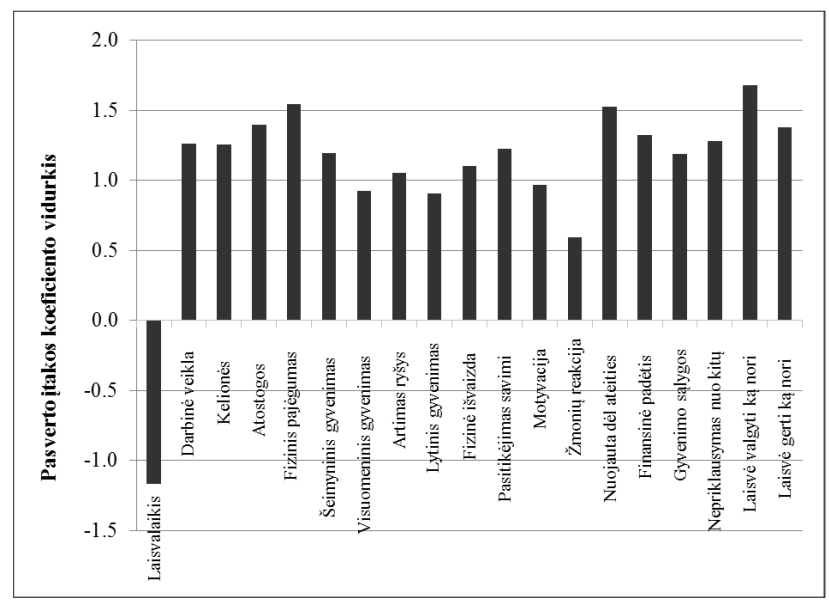

2 pav. Pagrindinių veiksnių, turinčių įtakos gyvenimo kokybei, pasiskirstymas, atsižvelgiant ị gydymo būdo tarpgrupinius įtakos koeficiento vidurkius (PĮKV - pasverto įtakos koeficiento vidurkis)

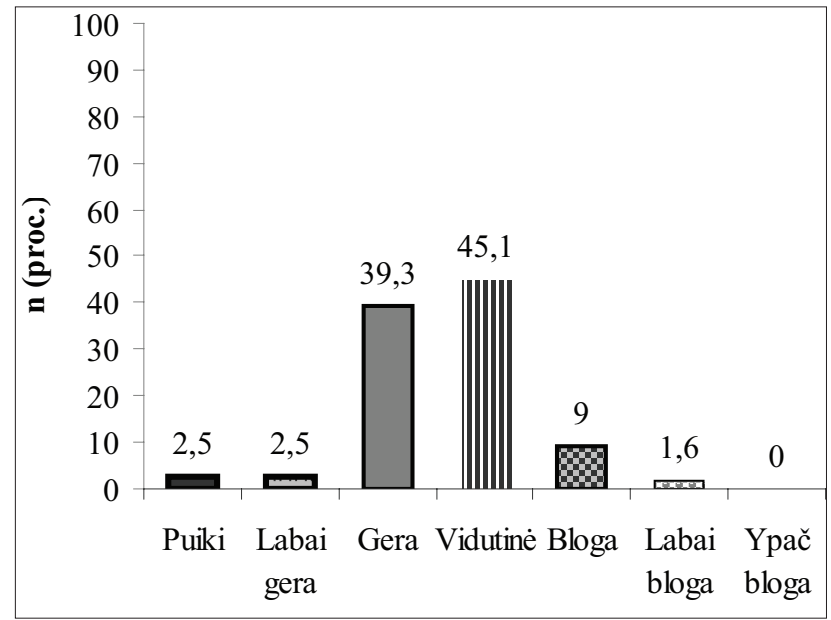

3 pav. Respondentų pasiskirstymas, vertinant dabartinę gyvenimo kokybę (proc.) proc.) mano, kad jų gyvenimo kokybė būtų truputi geresnè, jei jie nesirgtų CD. Tik dešimtadalis apklaustujų mano, kad jų gyvenimo kokybès nenulemia $\mathrm{CD}$.

Visuomeninis gyvenimas - vienas iš veiksnių, sąlygojančiu pacientu gyvenimo kokybę, taip pat buvo vertinamas šios apklausos metu. Didesnè respondentų grupé $\mathrm{n}=$ 64 (52,5 proc.) atsakè, kad visuomeninis gyvenimas ir santykis su draugais jiems yra ,svarbus“. Tik $\mathrm{n}=4$ (3,3 proc.) apklaustuju pasirinko neigiamą atsakymą i ši klausimą. Keturi iš dešimties mano, kad jų visuomeninis gyvenimas būtų toks pat, jeigu jie nesirgtų $C D \mathrm{n}=51$ ( 41,7 proc.). Vis tik daugiau apklaustujų galvoja, kad jų visuomeninis gyvenimas yra sąlygojamas $\mathrm{CD}$ ir būtų truputị geresnis, jeigu jie nesirgtų $n=71$ ( 58,9 proc.).

Slaugytojo diabetologo suteikiamų žinių ir mokymo apie CD ir prevenciją vertinimas sergančiųjų $C D$ požiūriu. CD sergančių asmenų žinios apie savo ligą ir sveikatą, igūdžiai ir mokymas yra svarbūs, siekiant keisti ipročius, išlaikyti ir stiprinti sveikatą. Kadangi CD valdymas net 95 proc. priklauso nuo sergančiojo savikontrolès, todèl pacientų ir jų šeimų mokymas bei konsultavimas užima svarbią vietą slaugos disciplinoje ir yra neatsiejama CD prevencijos dalis.

Dauguma apklaustų asmenų sutinka $\mathrm{n}=68(55,7$ proc. $)$, kad reikia kiekvienam išmanyti apie savo sveikatą. Buvo nustatytas ryšys tarp mokymosi, kaip išsaugoti ar stiprinti sveikatą (nesusirgti) ir pacientų žinių apie slaugytojo diabetologo teikiamas specializuotas slaugos paslaugas ( $\mathrm{r}$ $=0,138, p<0,05)$. Nestipri, tačiau reikšminga koreliacija buvo gauta tarp pacientų žinių apie slaugytojo diabetologo teikiamas specializuotas slaugos paslaugas ir savo žinių vertinimo $(r=0,129, p<0,05)$. Dauguma pacientų labai gerai ar net puikiai ịvertino slaugytojo diabetologo edukacinius gebejjimus. Mokymo programos informatyvumą ir suprantamumą pacientai daugiausia ìvertino labai gerai $\mathrm{n}=27$ (22,1 proc.) arba puikiai $n=34$ (27,9 proc.). Analogiškai pasiskirsté respondentų vertinimai, atsižvelgiant ị slaugy-

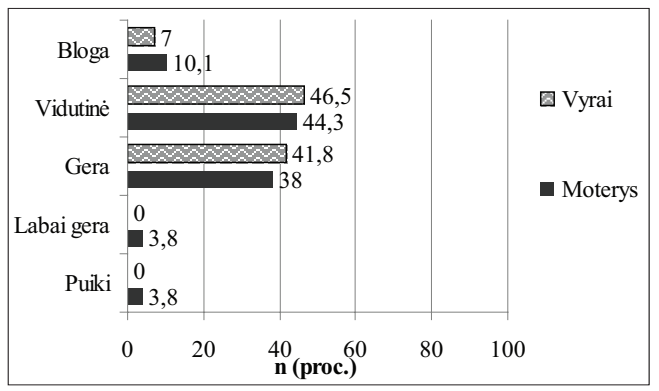

4 pav. Respondentų pasiskirstymas pagal lytị, vertinant numanomą gyvenimo kokybę, jeigu jie nesirgtų CD (proc.) 


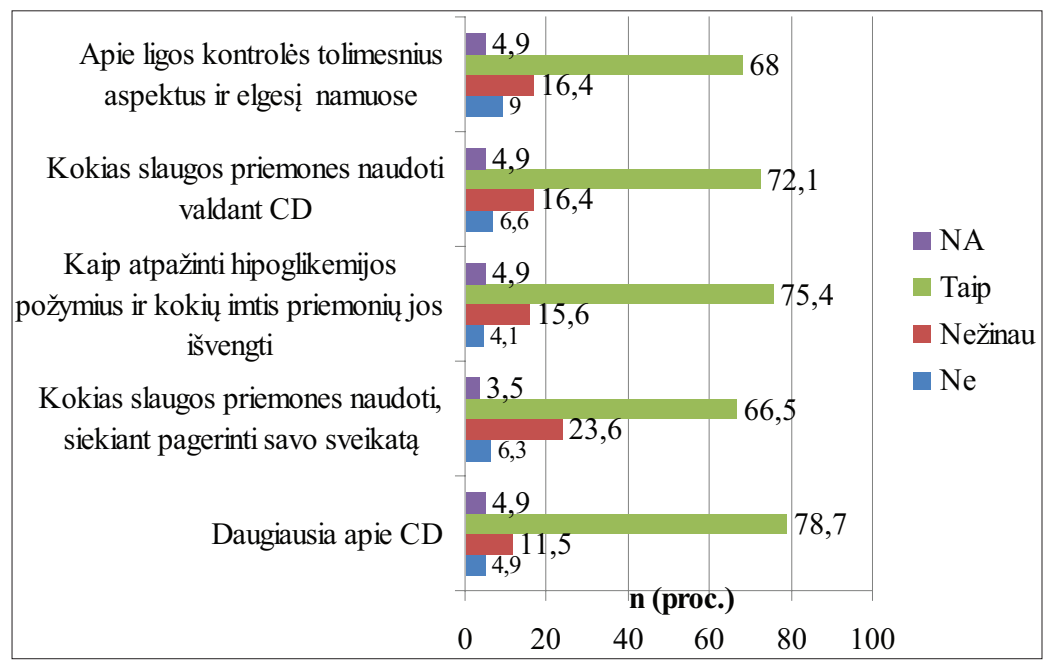

5 pav. Respondentų pasiskirstymas pagal informaciją, kurią pacientai sužinojo iš slaugytojo diabetologo (proc.)

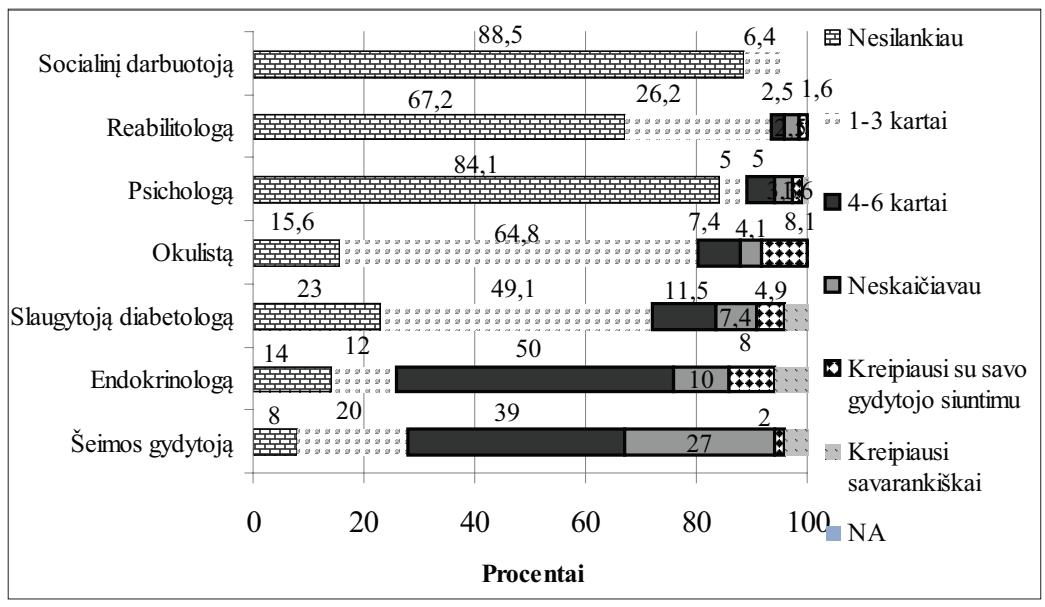

6 pav. Respondentų pasiskirstymas pagal lankymąsi pas specialistus, vertinant numanomą gyvenimo kokybę, jeigu jie nesirgtų CD (proc.)

tojo diabetologo asmenines savybes (apklausos dalyviai turèjo įvertinti slaugytojo diabetologo nuoširdumą, mokant pacientus), $\mathrm{n}=33$ (27 proc.) ivertino devyniais balais ir $\mathrm{n}$ $=43$ (35,2 proc.) ịvertino dešimt balų (1 lentelè).

Remiantis gautais duomenimis (5 pav.), daugiau kaip pusè respondentų nurode, kad sužinojo kaip atpažinti hipoglikemijos požymius ir kokių imtis priemonių, norint jos išvengti $n=92$ ( 75,4 proc.).

Reikšminga atvirkštinè koreliacija buvo gauta tarp pacientų žinių apie CD ir pacientų žinių apie slaugytojo diabetologo teikiamas specializuotas slaugos paslaugas $(\mathrm{r}=-$ $0,146, \mathrm{p}<0,05)$.

Taigi, didesnis informuotumas apie sveikatos priežiūros specialistų vaidmeni, valdant 2 tipo CD (2TCD), gali užkirsti kelią CD komplikacijoms ir pagerinti sergančiujų CD gyvenimo kokybę. Ši informacija turètų būti skelbiama ne tik sergantiems 2TCD, bet ir kitiems nariams bei visuomenei [22].

Per pastaruosius 12 mènesių pacientai nesikreipé i socialini darbuotoją $\mathrm{n}=$ 108 (88.5 proc.), psichologą $\mathrm{n}=105(84,1$ proc.), reabilitologą $n=80$ (67, 2 proc.), šiomis paslaugomis respondentai mažiausiai naudojosi (6 pav.).

\section{Rezultatų aptarimas}

Ivertinus pacientų, sergančių $\mathrm{CD}$, gyvenimo kokybę, nustatyta, kad 45,3 proc. pacientų dabartiné gyvenimo kokybė yra vidutiniška. Mažiau nei dešimtadalis apklausos dalyvių nurodè, kad jų gyvenimo kokybe yra labai bloga. Tačiau pacientu atsakymai apie numanomą jų gyvenimo kokybę, jeigu jie nesirgtu CD, rodo, kad 40,9 proc. respondentų suvokimu, liga nulemia jų gyvenimo kokybę, o 29,9 proc. atsaké, kad jų ateitis būtų daug geresné, jeigu ne CD.

Visuomeninis gyvenimas - vienas iš veiksnių, sąlygojančių pacientų gyvenimo kokybę, taip pat buvo vertinamas šios apklausos metu. Didesnè respondentų grupé $\mathrm{n}=64$ (52,5 proc.) atsake, kad visuomeninis gyvenimas ir santykis su draugais jiems yra „svarbus“. Didesnè dalis apklaustųjų galvoja, kad jų visuomeninis gyvenimas yra sąlygojamas CD ir būtų truputị geresnis, jeigu jie nesirgtu $n=71$ (58,9 proc.).

L. Okunevičiūtė Neverauskienè, J. Moskvina sako, kad remiantis aktyvaus senejjimo principu siekiama vyresnio amžiaus asmenų aktyvesnio dalyvavimo ekonomineje sistemoje ir visuomeniniame gyvenime ir tai yra laikoma svarbiais Europos socialinès politikos uždaviniais [32].

Visuomenès ištekliai didèja, kai senyvo amžiaus asmenys, sustiprinę gebejjimus, dalyvauja visuomenès gyvenime. Sąlygos, kurios asmeniui sudaro pačiam pasiekti didesnių galimybių, panaudojant ịgytus, išplètotus tam tikroje socialinèje aplinkoje gebejimus yra dalyvumas, jis yra svarbiausias žmogaus raidos komponentas, kuris padidina asmens bei visuomenès išteklius.

Senyvo amžiaus žmonių nedalyvavimas bendruomenès gyvenime yra susijęs su socialine atskirtimi, kurią lemia keletas faktorių tai - diskriminacija, nepakankami ịgūdžiai, prasta sveikata, šeimos problemos, socialinès paslau- 
1 lentelè. Slaugytojų diabetologų mokymų, žinių suteikimo ịvertinimas balais (1 balas - visiškai blogai, o 10 balų - puikiai)

\begin{tabular}{|c|c|c|c|c|c|c|c|c|c|c|c|c|}
\hline \multirow{2}{*}{$\begin{array}{l}\text { Vertinimo } \\
\text { kriterijus }\end{array}$} & \multirow{2}{*}{ Tiriamieji } & \multicolumn{10}{|c|}{ Ivertinimas balais } & \multirow{2}{*}{ NA } \\
\hline & & 1 & 2 & 3 & 4 & 5 & 6 & 7 & 8 & 9 & 10 & \\
\hline \multirow{2}{*}{$\begin{array}{l}\text { Mokymo programa } \\
\text { informatyvi, papras- } \\
\text { ta ir suprantama } \\
\text { pacientui }\end{array}$} & $\mathrm{n}$ & 3 & 2 & 5 & 3 & 8 & 8 & 6 & 16 & 27 & 34 & 10 \\
\hline & proc. & 2,5 & 1,6 & 4,1 & 2,5 & 6,6 & 6,6 & 4,9 & 13,1 & 22,1 & 27,9 & 8,2 \\
\hline \multirow{2}{*}{$\begin{array}{l}\text { Nuoširdumas mo- } \\
\text { kant }\end{array}$} & $\mathrm{n}$ & 3 & 2 & 2 & 2 & 8 & 5 & 3 & 11 & 33 & 43 & 10 \\
\hline & proc. & 2,5 & 1,6 & 1,6 & 1,6 & 6,6 & 4,1 & 2,5 & 9,0 & 27,0 & 35,2 & 8,2 \\
\hline \multirow{2}{*}{$\begin{array}{l}\text { Praktinių priemonių } \\
\text { naudojimas mokant }\end{array}$} & $\mathrm{n}$ & 5 & 3 & 4 & 1 & 6 & 5 & 6 & 15 & 33 & 34 & 10 \\
\hline & proc. & 4,1 & 2,5 & 3,3 & 8,0 & 4,9 & 4,1 & 4,9 & 12,3 & 27,0 & 27,9 & 8,2 \\
\hline
\end{tabular}

gos, informacijos nepasiekiamumas [33].

Slovenijoje darytame tyrime Turk E. ir kt., kuriame buvo tirta vyresnio amžiaus žmonių, sergančių 2 TCD gyvenimo kokybė, vertinant respondentų nuomonę apie laisvalaikio veiklą sutampa su mūsų gautais tyrimo rezultatais. Mūsų gautais duomenimis, dèl CD nukenčia sergančiujų CD laisvalaikio veikla $(-1,17 \pm 0,25)$, Turk E. ir kt. tyrime $(-1,1 \pm 0,7)[34]$.

CD sergančių asmenų žinios apie savo ligą ir sveikatą, ignūdžiai ir mokymas yra svarbūs, siekiant keisti elgseną, ịpročius, didinant savarankiškumą, išlaikyti ir stiprinti sveikatą. Remiantis apklausos duomenimis, galima teigti, kad daugiau kaip pusė respondentu sutinka, kad reikia kiekvienam išmanyti apie savo sveikatą, ligą ir mokytis, tai yra svarbu pačiam sergančiajam. Beveik pusė pacientu mano, kad sergantysis privalo žinoti, kas yra susiję su jo liga ir sveikata ir kad sveikatos mokymas yra gydymo dalis. Respondentų dalyvavimas pamokèlèse patvirtina, kad pacientai domisi savo liga: Tokie aktyvūs veiksmai rodo, kad pacientai bandè keisti su sveikata susijusią elgseną, suvokdami, jog jie serga ir nekeičiant elgesio, neturint žinių, igūdžių, gali būti sunku kontroliuoti CD.

Buvo nustatytas ryšys tarp mokymosi, kaip išsaugoti ar stiprinti sveikatą (nesusirgti) ir pacientų žinių apie slaugytojo diabetologo teikiamas specializuotas slaugos paslaugas $(r=0,138, p<0,05)$. Nestipri, tačiau reikšminga koreliacija buvo gauta tarp pacientų žinių apie slaugytojo diabetologo teikiamas specializuotas slaugos paslaugas ir savo žinių vertinimo $(r=0,129, \mathrm{p}<0,05)$.

Remiantis gautais duomenimis, daugiau kaip pusė respondentų nurodè, kad sužinojo, kaip atpažinti hipoglikemijos požymius ir kokių imtis priemonių, norint jos išvengti, $\mathrm{n}=92$ (75,4 proc.). Švedijoje atliktame tyrime teigiama, kad pablogėjusi gyvenimo kokybė yra hipoglikemijos pasekmè, o ypač pasikartojančios hipoglikemijos. Tiek pacientai, tiek sveikatos priežiūros sistema ir apskritai visuomenè patiria dideles išlaidas, susijusias su hipoglikemija. Strategija, sušvelninanti hipoglikemijos riziką, apima žinias apie būklę, pacientų, artimųų, sveikatos priežiūros paslaugų teikejjų švietimą ir tinkamų gliukozès koncentraciją kraujyje mažinančių vaistų pasirinkimą [31]. Atliktame sergančiujų CD, įrašytų Sveikatos, Senèjimo ir Kūno sandaros (,Sveikatos $\mathrm{ABC}$ () perspektyviniame didelès apimties kohortiniame tyrime, kuris prasidejo $1997 \mathrm{~m}$. ir jame dalyvavo daugiau nei 3075 ligonių, galutinę kohortos analizę sudare 783 tyrimo dalyviai - 25,4 proc. (783 iš 3075 ) nuo 70 iki 79 metų amžiaus, kurie buvo stebèti 12 metŭ. Vyresnio amžiaus ligoniai, sergantys CD ir dažnai kenčiantys nuo hipoglikemijos epizodų, kur kas labiau rizikuoja susirgti demencija. Atskleista, kad per tyrimo laiką beveik 20 proc. ligonių išsivyste demencija. Vyresnio amžiaus pacientams, kurie buvo gydomi ligoninèje dèl hipoglikemijos epizodų, demencijos rizika yra maždaug du kartus didesnè 21 iš 61 (34,4 proc.), palyginus su 127 iš 722 (17,6 proc.) su tais, kurie neturejo hipoglikemijos epizodu $(\mathrm{p}<.001)$ [30].

Per pastaruosius 12 mẻnesiu pacientai nesikreipe ị socialinį darbuotoją $n=108$ ( 88.5 proc.), psichologą $n=105$ ( 84,1 proc.), reabilitologą $n=80$ (67, 2 proc.), šiomis paslaugomis respondentai mažiausiai naudojosi. Anot J. Bogdanovos, N. P. Večkienès, tarpdisciplininė komanda, kuri naudoja skirtingas žinias ir informaciją, papildo bendrą, ,žinojimo bagažą“" kuria socialinị kapitalą, kadangi skirtingų specialistų bendradarbiavimas sąlygoja veiklos efektyvumą ir pokyčius. Kai socialiniai darbuotojai, medikai (slaugytojai diabetologai) siekia bendrų tikslų (pvz., gerina sergančiųjų CD priežiūrą) - plètojama socialinè partnerystė [20]. 


\section{Išvados}

1. Bendras respondentų gyvenimo kokybès vertinimo vidurkis 0,39 balo.

2. Dauguma respondentų sutinka, kad reikia kiekvienam išmanyti apie savo sveikata, domètis liga.

3. Daugiau nei pusė apklaustụjų buvo patenkinti teikiamomis slaugytojo diabetologo paslaugomis. Siekiant gerinti sergančiųu CD gyvenimo kokybę, svarbu rūpintis tiek fiziniais ligos kontrolès aspektais, tiek psichosocialiniais. Slaugytojas diabetologas siekia padèti sergantiems CD laikytis gydymo ir slaugos rekomendacijų, skatina elgsenos pokyčius ir jų išlaikymą, aiškinasi ir sprendžia kylančius neaiškumus.

4. Sergantieji CD tikisi tikslios, suprantamos informacijos apie savo ligą, jos baigti. Mokymas yra vienas iš veiksnių, darančių teigiamą ịtaką sergančiųu CD gyvenimo kokybei, nes tai sumažina CD komplikacijas, slaugos ir gydymo išlaidas.

\section{Literatūra}

1. Tamutienė I., Naujanienė R. Senyvo amžiaus asmenų socialinių paslaugų prieinamumo namuose patirtys. Tiltai, 2013; 4.

2. Higienos instituto Sveikatos informacijos centras. Pagrindinès sveikatos statistikos sąvokos, jų apibrèžimai ir skaičiavimas 2010 [žiūrèta 2016-02-10]. Prieiga per internetą: <http://sic. hi.lt/>.

3. McIlfatrick S, Murphy T. Palliative care research on the island of Ireland over the last decade: a systematic review and thematic analysis of peer reviewed publications. BMC Palliative Care 2013;12:33 http://dx.doi.org/10.1186/1472-684X-12-33

4. IDF Diabetes Atlas, 2015. International Diabetes Federation. IDF Diabetes Atlas, 7th edn. Brussels, Belgium: International Diabetes Federation, 2015 [online]. [cited 2016-01-21]. Availed from Internet: <http://www.idf.org/diabetesatlas

5. Higienos instituto Sveikatos informacijos centras 2012 [žiūrèta 2016-01-18]. Prieiga per internetą: <http://sic.hi.lt/>.

6. Nissen $\mathrm{H}$, Aagaard $\mathrm{H}$. The meaning of insulin pump therapy to adult patients with type 1 diabetes. 18th fend Foundation of European Nurses in Diabetes Annual Conference. Ispanija, Barselona, 2013; 27.

7. Jurgutis A., Juknevičiūtė V., Grubliauskienė J., Būtienė I., Kraniauskas L. Slaugytojų vaidmuo teikiant motyvacinio konsultavimo paslaugas lètinėmis neinfekcinèmis ligomis sergantiems pacientams. Visuomenès sveikata, 2013; 1.

8. Peimani M, Tabatabaei M. O., Pajouhi M. Nurses' role in diabetes care; A review. Iranian Journal of Diabetes and Lipid Disorders 2010; 9:1-9.

9. Pakpour AH, Saffari M, Burri A. Translation and validation of an Iranian version of the diabetes quality of life measure. Diabetes Investigation 2012;3.

10. Bliuvaitè S., Šinkariova L. Sergančiujų 2 tipo cukriniu diabetu sveikatos kontrolès lokuso, socialinio palaikymo bei pasitenkinimo suteikiama pagalba ligonineje sąsajos. Tarptautinis psichologijos žurnalas: biopsichosocialinis požiūris, 2012; 11:9-29. http://dx.doi.org/10.7220/1941-7233.11.1

11. Katzenellenbogen L. Assessement of the perceived impact of diabetes on a quality of life in a group of South African diabetic patients 2008.

12. Chehade JM., Wood DL., Fox L.A, Palacio C. Management of diabetes in the adolescent and young adult during transition. Northeast Florida Medicine 2008; 4(59).

13. Žydžiūnaitė V., Mitkienė L., Mikulevičienė A. Vadybinès kompetencijos realizavimas slaugoje. Mokslo studija. Klaipèda, 2007.

14. Freund S., Prašek M., Ajduković D. Knowledge alone does not improve glycemic control. 18th $\mathrm{fe}$ e d Foundation of European Nurses in Diabetes Annual Conference. Barselona, 2013; 26.

15. Miškinis K., Riklikienė O., Kaleddienė R., Jarašiūnaitė G. Lietuvos gyventojų informuotumas ir pasitikejjimas privalomojo sveikatos draudimo sistema. Visuomenès sveikata, 2011; 4:21.

16. Böstrom E., Isaksson U., Lundman B., Sjölander AE, Hörnsten $\AA$. Diabetes specialist nurses' perceptions of their multifaceted role. European Diabetes Nursing 2012;9(2):39-44. http://dx.doi.org/10.1002/edn.204

17. Lietuvos Respublika sveikatos apsaugos ministerija. Dèl sergančiųjų cukriniu diabetu slaugos paslaugų teikimo reikalavimų aprašo patvirtinimo. Vilnius, $2012 \mathrm{~m}$. spalio $10 \mathrm{~d}$. V-982. [interaktyvus]. [žiūrèta 2014-01-03]. Prieiga per internetą: $<$ http://www.sam.lt >

18. Petkevičius A., Lučun I. Kserozès ir nuospaudų formavimosi valdymas - svarbus diabetinès pėdos profilaktikos veiksnys. Lietuvos bendrosios praktikos gydytojas, 2010; (15):5.

19. Alhyas L., Nielsen JDJ., Dawoud D., Majeed A. Factors affecting the motivation of healthcare professionals providing care to Emiratis with type 2 diabetes. Journal of the Royal Society of Medicine Short Reports 2013;4:14. http://dx.doi.org/10.1177/2042533313476419

20. Bogdanova J., Večkienė N.P. Partnerystė rengiant socialinius darbuotojus: tarpdisciplininès komandos patirtis psichiatrijos skyriuje. Socialinis darbas. Patirtis ir metodai ISSN 2029-0470 2009; 3(1).

21. LR SAM. Strateginiai sveikatos srities vystymo iki $2025 \mathrm{~m}$. dokumentai [žiūrèta 2015-09-30]. Prieiga per internetą: $<$ http:// esparama.sam.lt/go.php/lit/Strateginiai-sveikatos-srities-vystymo-iki-2025-m-dokumentai>.

22. Šileikaitė S., Kudukytė-Gasperè R. Slaugos paslaugų teikimo modernizavimo problemos -Vilniaus miesto Centro poliklinikos patirtis. Sveikatos mokslai, 2011; 21(6):131-143.

23. Weinstein, Barbara E. Geriatric patient-centered care: hearing status plays integral part. Hearing Journal 2015; (86)5:16,18.

24. Gedvilaitè-Kordušienė M. Gyventojų senejjimas ir jo iššūkiai: suaugusiu vaiku pareigos pagyvenusiems tévams Lietuvoje. Lietuvos statistikos darbai, 2013; (52)1:22-33.

25. Stankūnienè V. Ar tolstame nuo 3 milijonų? VDU, Demografinių tyrimų centras. Demografija visiems, 2014; 1.

26. Abbaszadeh Ahranjani S., Tabatabaei Malazy O, Pajouhi M. Diabetes in old age, a review. Iranian Journal of Diabetes and Lipid Disorders; 2009; 113-128.

27. Kvietkutė I. Specialių pusiausvyrą lavinančių pratimų poveikis pagyvenusių moterų griuvimų rizikai. Magistro darbas. Kaunas 2010. 
28. Kardelis K. Mokslinių tyrimų metodologija ir metodai. 2-asis leidimas, 2002 metai, Šiauliai.

29. Muchlytė E., Visockienẻ Ž. Ligai specifinis diabetu sergančiujju gyvenimo kokybės tyrimas VUL SK. Vilniaus universiteto Medicinos fakulteto Studentų mokslinès draugijos LXV kon $\urcorner$ ferencijos darbų tezių medžiaga. [Vilnius, $2013 \mathrm{~m}$. balandžio 17 d. - gegužès 3 d.]. Vilnius, 256.

30. Yaffe K, Falvey ChM, Hamilton N. et al. Association between hypoglycemia and dementia in a biracial cohort of older adults with diabetes mellitus. [online].[cited 2016-02-22]. From JAMA Intern Med. 2013;173(14):1300-1306. http://dx.doi.org/10.1001/jamainternmed.2013.6176

31. Ahrén Bo. Avoiding hypoglycemia: a key to success for glucose-lowering therapy in type 2 diabetes [online].[cited 2016-02-22]. From Lund university libraries. Available from Internet $:<$ http://lup.lub.lu.se/record/3805000.

32. Okunevičiūtè Neverauskienè L., Moskvina J. Vyresnio amžiaus asmenų situacijos pokyčiai. Socialinis ekonominis kontekstas. Gerontologija, 2013; 14(1):46-59. [online].[cited 2016-05-22]. From JAMA Intern Med.

33. Čepėnaite A D. Senyvo amžiaus žmonių socialinė aprèptis ir demokratinio pilietiškumo apraiškos. Socialinis darbas, 2008;7(1).

34. Turk E. et al. Reliability and validity of the audit on diabetesdependent quality of life (addqol) and eq-5d in elderly slovenian diabetes mellitus type 2 patients. Health, 2014; 6:699-711. http://dx.doi.org/10.4236/health.2014.68091

\section{LINK BETWEEN NURSE'S ROLE IMPROVING CARE OF THE OLDER PERSONS WITH DIABETES MELLITUS AND PATIENTS' QUALITY OF LIFE \\ B. Bartkevičiūtė, E. Venskaitytė, J. Samėnienė, \\ A. Blaževičienè, V. Bulikaitė}

Key words: diabetes nurse, quality of life in patients with diabetes, diabetes, older patient.

Summary

Lithuanian, like other European countries, society is rapidly aging. Changing demographic trends: an aging population, increased life expectancy, people with physical, psychological and social well-being affected by chronic diseases (eg., diabetes mellitus (DM), osteoarthritis). As a result, many old people are in need of various services.

According to numerous Lithuanian studies, there is a significant increase in population with Diabetes Mellitus (DM). This chronic disease leads to significant morbidity and mortality. Thus, DM among older elderly is a strong public health challenge. Older patient who experienced a hypoglycemic event had a increased risk for developing dementia compared with those who did not have a hypoglycemic event.

The main purpose of this work is to determine the diabetes nurse 's influence on learning about the disease and the quality of life in older patients with DM.
Methods. Survey was conducted at the Lithuanian Diabetes Association (LDA) from 2013 March till December 2013. The anonymous questionnaire was applied. 122 members of LDA were involved in this study: 60 years and older patients with $1^{\text {st }}$ or $2^{\text {nd }}$ type DM. Statistical analysis was performed by using IBM SPSS Statistics software, version 19.0.

Instrument. The ADDQOL consists of two overview items: one measures generic overall QOL and a further 19 items are concerned with the impact of diabetes on specific aspects of life. The 19 life domains are as follows: leisure activities, working life, local or long-distance journeys, holidays, physical health, family life, friendships and social life, close personal relationships, sex life, physical appearance, self-confidence, motivation to achieve things, people's reactions, feelings about the future, financial situation, living conditions, dependence on others, freedom to eat, and freedom to drink. These 19 domains ask the respondents to evaluate how their life would be if they did not have diabetes mellitus. The scales range from -3 to +1 for 19 life domains (impact rating) and from 0 to +3 in attributed importance (importance rating). A weighted score for each domain is calculated as a multiplier of impact rating and importance rating (ranging from -9 to +3 ). Lower scores reflect poorer QOL. Finally, a mean weighted impact score (ADDQOL score) is calculated for the entire scale across all applicable domains.

Results. More than half of respondents $(\mathrm{n}=55(45.1 \%)-0.39$ $(0.770))$ indicated that their current quality of life was average. Four out of ten reported that their life would have been better if they did not have $\mathrm{DM} \mathrm{n}=46(37.8 \%) 2.41(0.092)$. There was a significant, inverse correlation between learning how to stay healthy and patient's knowledge about specialized nursing care provided by diabetes nurse $(\mathrm{r}=-0.146, \mathrm{p}=0.020)$. Most patients rated educational capability of diabetes nurses with the patients as being good or excellent.

Conclusions. Diabetes nurse is seeking to help with DM to follow treatment and care guidelines to promote behavioral change and maintenance, clarifys and resolves the arising uncertainties. Training is one of the factors that have a positive impact on the quality of life of patients with DM. The overall quality of life of the respondents averaged $0,39 \pm 0,770$. Most respondents agreed that everyone should be aware of and learn about theirs health condition. Diabetes nurse initiates patient's education. Respondents were satisfied with the diabetes nurse's services.

Correspondence to: birutebart@hotmail.com

2016-07-17 